tion of weeds blocking the canals and drains of the Nile Delta. With the help of two of his assistants, he undertook to investigate for the Ministry of Public Works this serious interference with the system of irrigation.

As a teacher and organiser of research Lewis was most successful, as can be gathered from the rapid growth of his Department and from the fact that many of his students stayed on to prepare for the M.Sc. and Ph.D. degrees by research. During the earlier years of his stay in Egypt, the Faculty of Science was housed in an old palace at Abbassia between Cairo and Heliopolis, but for his growing department a new and more spacious laboratory was planned at Giza, the main site of the University (Nature, July 13, p. 43). With infinite tact and patience Lewis overcame all the difficulties this proposal involved and he now leaves the Botanical Department adequately housed for the accommodation of about 1,200 students and the large staff of lecturers and demonstrators. Fortunately, during the last few years Lewis has had the help of another professor, Prof. Y. S. Sabet, who has been a most loyal colleague. With both his students and his staff Lewis has been deservedly popular. Thus Prof. Lewis can now look back on his ten years of hard work in Cairo with complete, as well as pleasurable, satisfaction, and perhaps that has enabled him, in spite of a trying climate and wartime conditions, to retain abundant physical and mental energy.

\section{Botany at University College of Science, Calcutta Prof. S. P. Agharkar}

Prof. Shankar Purusottam Agharkar, of the University College of Science, Calcutta, has retired after thirty-two years of service. Prof. Agharkar was appointed/Ghose professor of botany in 1914 and deputed/to Germany for further studies. In Berlin he gtudied under A. Engler, L. Diels, G. Haberlandt and others and obtained the doctorate of the Uniyersity in 1919. In the meantime, with the inauguration of the Post-Graduate Department of the Univorsity of Calcutta, the palatial residential building of the late Sir Tarak Nath P'alit at Ballygunge was converted into the Biological Laboratory and Prof. Paul Brühl was placed in charge of the Botany Department. $\mathrm{H}_{\theta}$ equipped it on a large scale in different branches of botany and initiated research work by students at the University. Prof. Agharkar returned to the University in 1920 . In 1929 he took complete charge of the Department after the retirement of Prof. Brühl. From then onwards, Agharkar succeeded in increasing the number of members of the teaching staff for the different branches of botany, so that to-day facilities for research in mycology, cytogenetics, physiology and palæobotany, etc., are available in the laboratory, and much good work has been published.

Throughout his career, Prof. Agharkar has played a prominent part in the different scientific societies of India : he presided over the Botany Section of the Indian Science Congress in 1924 ; he was president of the Indian Botanical Society in 1934; hon. secretary of the Indian Society of Soil Sdence (193540) ; president of the Botanical Society' of Bengal (1939-42) ; president of the Indian Ecological Society (1944-46); biological secretary of the Royal Asiatic Society of Bengal (1943-44). He has been a member of the Committees of the Imperial Council of Agricultural Research since 1930 , of the Indian Central
Jute Committee since its establishment, of the governing body of the Indian Research Fund Association 1939-42. He played a prominent part in organising the scientific activities of the two wellknown All India scientific organisations, namely, the Indian Science Congress Association as its general secretary from 1924 until 1934 and the National Institute of Sciences of India as its honorary secretary during 1935-45.

Prof. P. C. NSArod Prof. P. C. Sarbadhikari, who succeeds Prof. Agharkar if a Ghose professorship of botany at the Uniyersidy College of Science, Calcutta, is a former pupil of the late Sir John Bretland Farmer, at the Ifpe jal College of Science and Technology, London, where he obtained the degree of D.Sc. in the University of London and won distinction as a research student. His original work has been mainly cytological, and in this field he has made notable contributions to our knowledge of the life-histories of fungi, ferns and flowering plants. Both as a student and while on leave as a teacher at Colombo he made wide contacts, by working at the Royal Botanic Gardens, Kew, at the John Innes Horticultural Institution during the time of Bateson, at the Jodrell Laboratory with Miss Digby, and in Paris where he worked under Guillermond. For many years associated with the University of Ceylon, first as a lecturer and later as professor of botany, Sarbadhikari returns with a long and varied experience to the University of Calcutta where he had first graduated a quarter of a century ago.

Civil Engineering at King's College, London : Prof.

\section{A. D. Ross}

Dr. A. D. Ross, who will succeed Prof. C. H. Lobban in the University of London chair of eivil engineering, aA King' SCollege (see Nature, July 20, p. 91), graf (vated at Edinburgh in 1929. After some yeans ip professiofal civil engineering on railway and roaff cartstructiof, he returned to the University of Ednourgh as an assistant in the Engineering Department under the late Sir. T. Hudson Beare. He left Edinburgh to serve for a time as an education officer with the Air Ministry, and since 1935 he has held the appointment of lecturer in the Department of Civil and Mechanical Engineering at King's College, London. Dr. Ross's main interest has been in the field of concrete and reinforced concrete, and he has studied especially the non-elastic deformations in this material and their effects on the stress distribution in structures. His earlier work was concerned with an analysis of the numerous factors controlling creep, and he has devoted attention to the influence of the ratio of surface area to volume on the magnitude and distribution of shrinkage. Subsequent work has been concerned with the application of the knowledge of creep and shrinkage to reinforced concrete structures, and he has obtained solutions to a variety of problems in the distribution of stress by means of an idealized Voigt model. The results of his researches have been communicated in papers published by the Institution of Civil Engineers and other technical bodies.

\section{International Federation of University Women}

THE International Federation of University Women is holding jts twenty-sixth Council meeting-the first since the War-at Crosby Hall, Chelsea, by 